\title{
Bag Device
}

National Cancer Institute

\section{Source}

National Cancer Institute. Bag Device. NCI Thesaurus. Code C49834.

A flexible container, often with a single opening. 